\title{
Yield and Nutritional Quality Traits of White Lupin Sprouts
}

\author{
Harbans L. Bhardwaj (Corresponding Author) \\ Agricultural Research Station, Virginia State University, PO Box 9061, Petersburg, VA 23806, USA \\ Tel: 1-804-524-6723 E-mail: hbhardwj@vsu.edu
}

Anwar A. Hamama

Agricultural Research Station, Virginia State University, PO Box 9061, Petersburg, VA 23806, USA

Tel: 1-804-524-6822Ｅ-mail: ahamama@vsu.edu

$\begin{array}{lc}\text { Received: March 26, } 2011 & \text { Accepted: April 12, } 2011 \quad \text { Online Published: December 1, } 2011 \\ \text { doi:10.5539/jas.v4n1p58 } & \text { URL: http://dx.doi.org/10.5539/jas.v4n1p58 }\end{array}$

\begin{abstract}
Use of mature lupin seeds for human nutrition has been prevalent since ancient times. Lupin seed have been used as food for over 3000 years around the Mediterranean and for as much as 6000 years in the Andean highlands. However, no information is available about value-added products from lupin, especially white lupin (Lupinus albus L.), for human consumption. We prepared sprouts from seed of eight white lupin genotypes, grown at two locations in Virginia during 2003-04 crop season. These sprouts were analyzed for various traits. Location effects were significantly for all traits except for moisture content of sprouts whereas genotypic effects were significant only for fresh sprout yield. The mean values for fresh yield (g) and contents (percent on dry weight basis) of moisture, crude fiber, oil, and protein, in white lupin sprouts were 74.8, 78.4, 16.7, 7.6, and 41.3, respectively. Oil and protein contents of white lupin sprouts were similar to alfalfa sprouts whereas white lupin sprouts had higher contents of oil and protein than mungbean sprouts. Based on crude fiber content, white lupin sprouts were superior to alfalfa and mungbean sprouts. Results indicated that white lupin sprouts have potential as human food.
\end{abstract}

Keywords: Lupinus albus L., Winter grain legume, Nutritional quality, Protein content, Oil content, Fiber content

\section{Introduction}

Sprouts from seeds of various grain crops are considered healthy for human consumption. Numerous studies have demonstrated that sprouts are one of the most complete and nutritious foods (Lorenz, 1980; Kaur and Kawatra, 2002; Bau et al., 1997; Yang et al., 2001). Sprouts are considered a predigested food, with higher biological efficiency values and lower levels of antiphysiologic factors than raw or cooked seeds (Balasaraswathi and Sadasivam, 1997; Chung et al., 1989). Sprouts have been observed to contribute extensively to the immune system, as excellent detoxificants (Andarwulan et al., 1999; Yang et al., 2001).

We are evaluating white lupin (Lupinus albus L.), as a new and alternative crop for the mid-Atlantic region of the United States of America. Lupin is a cool-season legume plant native to Mediterranean, North Africa, and North and South America. More than 300 Lupinus have been described, but only five species are cultivated. The most important are the white lupin, blue or narrow-leafed lupin (L. angustifolius L.), and yellow lupin (L. luteus L.). Andean lupin from South America (L. mutabilis L.) and the West Australian Sandplain or blue lupin ( $L$. consentinii L.) are grown on a limited basis because of their hard seed and high alkaloid content (Field and Putnam, 1993).

Even though mature lupin seeds have been used as food for over 3000 years around the Mediterranean and for as much as 6000 years in the Andean highlands, no information about lupin=s use as sprouts is available. We were able to find one reference in the literature (Dagnia et al., 1992) indicating that lupin seeds can also be germinated to make a big sprout for vegetable or salad use. Sprouting was shown to reduce alkaloids, phytate, and oligosaccharides in lupin seed.

Our objectives were characterization of sprouts made from white lupin seeds for yield and nutritional traits. We 
also compared the nutritional quality traits of white lupin sprouts with literature values of sprouts made from seeds of alfalfa, canola, mungbean, and radish.

\section{Materials and Methods}

\subsection{Sites and Their Characteristics}

The lupin seeds, used for sprout making, were produced in field experiments at two locations in Virginia: Petersburg, and Suffolk in the 2003-04 crop growing season. The soil type at Petersburg was an Abel sandy loam with a $\mathrm{pH}$ of 6.2, and the soil at Suffolk was a Raines fine sandy loam with a $\mathrm{pH}$ of 5.6.

\subsection{Treatments and Experimental Design}

Mature seeds from eight white lupin lines were used for these studies. These field experiments consisted of four replications and were planted in the fall season of 2003 and harvested during the summer of 2004.

\subsection{Agronomic Practices}

The field experiments were planted on September 27, and September 26, respectively for Petersburg, and Suffolk locations during 2003. Each plot consisted of four rows spaced $37.5 \mathrm{~cm}$ apart. Each row was $4.5 \mathrm{~m}$ long. The plot size was $6.75 \mathrm{~m}^{2}$. All field experiments received 1 pint per acre of Treflan (Trifluralin) as a pre-plant incorporated herbicide approximately one week before planting.

\subsection{Procedures}

Twenty gram seed from each of four replications were sprouted for 6 days, in a wide mouth jar $(9 \mathrm{~cm} \mathrm{x} 9 \mathrm{~cm} \mathrm{x}$ $16 \mathrm{~cm})$ covered with a mesh screen top to insure sufficient air ventilation, under laboratory conditions $\left(22^{\circ} \mathrm{C}\right.$ temperature and $98 \%$ relative humidity and room lighting, 375 lux for $10 \mathrm{~h}$ ). Following initial hydration (seeds were first soaked in room temperature water overnight), seeds were kept moist by rinsing and draining twice a day and the jars inverted at a slight angle until the next rinse (from 8 to $10 \mathrm{~h}$ ). At the end of sprouting, the fresh weights were recorded and expressed as fresh yield in $\mathrm{g}$. The sprouts were then dried at $65^{\circ} \mathrm{C}$ until constant weight. Dried sprouts from replications one and two were combined to make one bulk sample and seeds from replications three and four were combined to make a second bulk sample. These bulks were used for determinations of crude fiber, oil, and protein contents in sprouts.

\subsection{Data collection and Statistical Analysis}

Chemical composition of white lupin sprouts were determined by a commercial laboratory (A\&L Agricultural Laboratory, Richmond, VA) according to AOAC standard methods (AOAC, 1995). Protein content was calculated as $\mathrm{N} \times$ 6.25. The oil was extracted from two $\mathrm{g}$ each of ground dried canola sprouts at room temperature by homogenization with hexane/ isopropanol (3:2, v/v) as described by Hamama et al (2003). The oil was extracted three times from each sample and bulked to ensure full oil recovery. The oil content was determined gravimetrically after drying under vacuum at $40^{\circ} \mathrm{C}$ and stored under nitrogen at $10^{\circ} \mathrm{C}$ until analysis. The oil content was expressed as g. $100^{-1} \mathrm{~g}$ dried sprouts.

All data were analyzed by analysis of variance procedures (PROC GLM) in version 6.11 of SAS (SAS, 1996). LSD test was used for mean separation with a significance level of 5\%. The composition data from canola sprouts were compared to the values for alfalfa, Brussels sprouts, mungbean, and radish sprouts.

\section{Results and Discussion}

\subsection{Effect of locations and genotypes}

Significant differences existed among eight white lupin lines for fresh yield (g). Differences among eight lines were not significant for contents of moisture, oil, protein, and crude fiber (\%) with mean values of 78.4, 7.6, 41.3, and 16.7, respectively (Table 1). Sprouting resulted, on an average, in an increase of 3.74 times the weight of seeds before sprouting with fresh yield varying from $61.8 \mathrm{~g}$ (For L2412) to $80.0 \mathrm{~g}$ (For L2408).

Location effects were significant for fresh yield and contents of protein, crude fiber, and oil (Table 2) with seeds produced at Petersburg location resulted in superior contents of oil and protein (8.3 and 42.7 percent, respectively) over sprouts made from seed produced at Suffolk location (6.9 and 39.9 percent, respectively). However, seeds produced at Suffolk location resulted in sprouts with significant higher values of fresh yield and crude fiber (Table 2).

\subsection{Lupin sprouts vs. Alfalfa and Mungbean sprouts}

We compared contents of oil, protein, and crude fiber in white lupin sprouts produced in our study to those for alfalfa and mungbean reported in the literature (Table 3). These comparisons indicated that white lupin sprouts 
were similar to alfalfa sprouts, both being considerably superior to those made from mungbean. With regards to protein content, sprouts made from white lupin were 8 percent lower than those from alfalfa but 23 percent superior than mungbean sprouts. Alfalfa sprouts had considerably superior crude fiber as compared to both white lupin and mungbean sprouts.

\subsection{Potential of white lupin sprouts}

Results of this preliminary study indicated that white lupin sprouts can be a viable product for human consumption. We did not record the size of white lupin sprouts but visual observations indicated that these sprouts were considerably larger than sprouts from seeds of other crops, such as canola and mungbean made in our program. Larger size of white lupin sprouts may be desired by some consumers who are interested in large sized sprouts.

Information about food uses of white lupin is scarce even though seeds of other species have a long history of human consumption. Sipsas (2008) indicated that Australian sweet lupin (L.angustifolius L.) has amazing attributes in terms of health benefits particularly for concerns related to obesity, high blood pressure, insulin resistance, and elevated blood cholesterol. We propose that white lupin seeds and products should be evaluated further for human consumption.

\section{Conclusion}

This study demonstrates that use of white lupin seeds to produce nutritious sprouts for human consumption may be a viable option. Use of lupin sprouts has the potential to provide a new and alternative source of sprouts, thus, providing additional sources of sprouts for human consumption. Use of lupin sprouts for human consumption could also help in establishment of this crop as an alternative winter legume crop.

\section{Acknowledgements}

Contribution of Virginia State University, Agricultural Research Station, Journal Article Series No. 282. Use of any trade names or vendors does not imply approval to the exclusion of other products or vendors that may also be suitable. Funding support from U.S. Department of Agriculture, National Institute of Food and Agriculture, 1890 Institutions Capacity Building Grant Program is greatly appreciated.

\section{References}

AOAC. (1995). Official Methods of Analysis. Association of Official Analytical Chemists. $16^{\text {th }}$ Edition. Arlington, VA 22001.

Andarwulan N., D. Fardiaz, G.A. Wattimena, \& K. Shetty. (1999). Antioxidant Activity. Associated with Lipid and Phenolic Mobilization during Seed Germination of Pangium edule Reinw. J Agric Food Chem, 47:3158-3163 http://dx.doi.org/10.1021\%2Fjf981287a

Balasaraswathi, R., \& S. Sadasivam. (1997). Changes in oil, sugars and nitrogenous components during germination of sunflower seeds, Helianthus annuus. Plant Foods Hum. Nutr., 51:71-77. http://dx.doi.org/10.1023\%2FA\%3A1007924026633

Bau, H.M., C. Villaume, J.P. Nicolas, \& L. Mejean. (1997). Effect of germination on chemical composition, biochemical constituents and ant nutritional factors of soya bean (Glycine max) seeds. Journal of the Science of Food and Agriculture, 73:1-9. http://dx.doi.org/10.1002/(SICI)1097-0010(199701)73:1<1::AID-JSFA694>3.0.CO;2-B

Chung, T.Y, E.N. Nwokolo, \& J.S. Sim. (1989). Compositional and digestibility changes in sprouted barley and canola seeds. Plant Foods Hum. Nutr, 39:267-278. http://dx.doi.org/10.1007\%2FBF01091937

Dagnia, S.G., D.S. Petterson, R.R. Bell, \& F.V. Flanagan. (1992). Germination alters the nutritional value of lupin seed. Journal of the Science of Food and Agriculture, 60: 419-423. http://dx.doi.org/10.1002\%2Fjsfa.2740600403

Field, L.A. \& D.H. Putnam. (1993). Crop production, growth and development. In R.A. Meronuck, H. Meredith, $\&$ D.H. Putnam (ed.) Lupin Production and Utilization Guide. Center for Alternative Plant and Animal Products, University of Minnesota, St. Paul, MN., p. 3-4.

Hamama, A.A., H.L. Bhardwaj, \& D.E. Starner. (2003). Genotype and growing location effects on phytosterols in canola oil. J. Amer. Oil Chemists Soc., 80:1121-1126. http://dx.doi.org/10.1007\%2Fs11746-003-0829-3

Kaur, M. \& B.L. Kawatra. (2002). Effect of domestic processing on zinc bioavailability from ricebean (Vigna umbellata) diets. Plant Foods Hum. Nutr., 57:307-318. http://dx.doi.org/10.1023\%2FA\%3A1021848916175

Lorenz, K. (1980). Cereal sprouts: Composition, nutritive value, food applications, Crit. Rev. Food Sci. Nutr., 


\section{3:353-85. http://dx.doi.org/10.1080\%2F10408398009527295}

SAS. (1996). SAS System for Windows. SAS Institute, Inc., Cary, NC.

Sipsas, S. (2008). Lupin products - Concepts and reality. In J.A. Palta and J.B. Berger (eds.) Lupins for Health and Wealth. Proceedings of the $12^{\text {th }}$ International Lupin Conference, 14-18 September 2008, Freemantle, Australia. 506-513.

Yang, F., T.K. Basu, \& B. Ooraikul. (2001). Studies on germination conditions and antioxidant contents of wheat grain. Int. J. Food Sci. Nutr., 52 (4):319-330. Accession Number IND23231762

Table 1. Fresh yield and contents of moisture, oil, protein, and crude fiber in white lupin sprouts produced from seeds of eight genotypes grown during 2003-04 crop season at Petersburg and Suffolk locations in Virginia

\begin{tabular}{|l|l|l|l|l|l|}
\hline Cultivar & Fresh yield $(\mathrm{g})^{\mathrm{x}}$ & Moisture (\%) & Oil (\%) & Protein (\%) & Crude fiber (\%) \\
\hline L2404 & $76.0 \mathrm{a}^{\mathrm{y}}$ & $78.5 \mathrm{a}$ & $8.13 \mathrm{a}$ & $40.5 \mathrm{a}$ & $15.6 \mathrm{a}$ \\
\hline L2408 & $80.0 \mathrm{a}$ & $78.9 \mathrm{a}$ & $7.67 \mathrm{a}$ & $44.6 \mathrm{a}$ & $15.0 \mathrm{a}$ \\
\hline L2411 & $77.0 \mathrm{a}$ & $78.7 \mathrm{a}$ & $7.62 \mathrm{a}$ & $43.0 \mathrm{a}$ & $14.7 \mathrm{a}$ \\
\hline L2412 & $61.8 \mathrm{~b}$ & $78.3 \mathrm{a}$ & $7.68 \mathrm{a}$ & $40.3 \mathrm{a}$ & $16.0 \mathrm{a}$ \\
\hline L2415 & $72.0 \mathrm{a}$ & $78.4 \mathrm{a}$ & $7.97 \mathrm{a}$ & $40.8 \mathrm{a}$ & $15.9 \mathrm{a}$ \\
\hline L2417 & $78.1 \mathrm{a}$ & $78.3 \mathrm{a}$ & $6.70 \mathrm{a}$ & $40.5 \mathrm{a}$ & $17.2 \mathrm{a}$ \\
\hline L2420 & $76.2 \mathrm{a}$ & $78.9 \mathrm{a}$ & $7.62 \mathrm{a}$ & $40.7 \mathrm{a}$ & $15.6 \mathrm{a}$ \\
\hline L2424 & $77.0 \mathrm{a}$ & $77.3 \mathrm{a}$ & $7.47 \mathrm{a}$ & $40.0 \mathrm{a}$ & $15.6 \mathrm{a}$ \\
\hline Mean & 74.8 & 78.4 & 7.61 & 41.3 & 16.7 \\
\hline
\end{tabular}

$\mathrm{x}$ : $\quad$ From $20 \mathrm{~g}$ seed. Location $\mathrm{x}$ cultivar interaction mean squares for all traits were non-significant. Means over 2 locations and two replications.

y Means followed by similar letter were not different according to Least Significant Difference at 5\% level of significance.

Table 2. Location effects on fresh yield and contents of moisture, oil, protein, and crude fiber in white lupin sprouts from eight genotypes grown during each of 2003-04 at Petersburg and Suffolk locations in Virginia

\begin{tabular}{|l|l|l|l|l|l|}
\hline Location & Fresh yield $(\mathrm{g})^{\mathrm{x}}$ & Moisture (\%) & Oil (\%) & Protein (\%) & Crude fiber (\%) \\
\hline Petersburg & $72.8 \mathrm{~b}^{\mathrm{y}}$ & $78.1 \mathrm{a}$ & $8.3 \mathrm{a}$ & $42.7 \mathrm{a}$ & $15.0 \mathrm{~b}$ \\
\hline Suffolk & $76.8 \mathrm{a}$ & $78.7 \mathrm{a}$ & $6.9 \mathrm{~b}$ & $39.9 \mathrm{~b}$ & $16.4 \mathrm{a}$ \\
\hline Mean & 74.8 & 78.4 & 7.61 & 41.3 & 16.7 \\
\hline
\end{tabular}

$\mathrm{x}$ : $\quad$ From $20 \mathrm{~g}$ seed. Location $\mathrm{x}$ cultivar interaction mean squares for all traits were non-significant. Means over 2 locations and two replications.

y Means followed by similar letter were not different according to Least Significant Difference at 5\% level of significance.

Table 3. Comparison of composition of white lupin, alfalfa, and mungbean sprouts

\begin{tabular}{|l|l|l|l|}
\hline Cultivar & Oil (\%) & Protein (\%) & Crude fiber (\%) \\
\hline White lupin $^{\mathrm{x}}$ & 7.6 & 41.3 & 16.7 \\
\hline Alfalfa $^{\mathrm{y}}$ & 7.8 & 45.0 & 25.2 \\
\hline Mungbean $^{\mathrm{y}}$ & 1.9 & 31.7 & 18.7 \\
\hline
\end{tabular}

$\mathrm{x} \quad$ Means of 8 genotypes grown during 2003-04 crop season at Petersburg and Suffolk locations in Virginia.

y: Values from Nutrient Database for Standard Reference, Release 14. USDA-ARS Nutrient Data Laboratory (Home Page: http://www.nal.us) 